\title{
POLA ASUH TERHADAP ANAK DISABILITAS PADA MASA PANDEMI DI SLB NEGERI SUKADANA KALIMANTAN BARAT
}

\author{
Furi Novita \\ Politeknik Kesejahteraan Sosial Bandung, furry.novita@gmail.com \\ Dwi Yuliani \\ Politeknik Kesejahteraan Sosial Bandung, dwi_stks@yahoo.co.id
}

\begin{abstract}
Parenting patterns for children with disabilities are indispensable especially in the condition of the covid-19 pandemic. This study aims to obtain an in-depth picture of :1) characteristics of parents and children with disabilities, 2) parental supervision of children with visual impairment, 3) parental communication of children with visual impairment, 4) parental discipline of children with disabilities. This study uses descriptive qualitative method with data collection techniques, namely: 1) in-depth interviews, 2) observations, 3) documentation studies. The source of this research data is the primary data source, namely parents of children with disabilities and secondary data sources in the form of documentation or other information. The results of this study raised 5 problems found in the field, namely children's association during the covid-19 pandemic, children's behavior playing gadgets during the covid-19 pandemic, maintaining health protokols, the Home Learning system during the covid-19 pandemic, and maladaptive behavior of children with visual disabilities. This study gives the insight that the care applied by parents is still not maximal, especially in communicating and disciplining children with disabilities. Parents experience obstacles in communicating with children with visual impairment because the intelligence condition of the child causing the child difficult to interact whether it is saying a word, knowing vocabulary and remembering something. In the discipline aspect parents do not apply discipline to children with disabilities whether it is the discipline of time in doing activities or disciplining the child to adhere to health protokols.
\end{abstract}

Keywords:

Parenting Patterns, Children with Disabilities 


\begin{abstract}
Abstrak
Pola asuh orangtua terhadap anak intelektual sangat diperlukan terutama pada kondisi pandemi covid-19. Penelitian ini bertujuan untuk memperoleh gambaran mendalam tentang :1) karakteristik orangtua dan anak intelektual, 2) pengawasan orangtua terhadap anak intelektual, 3) komunikasi orangtua terhadap anak intelektual, 4) disiplin orangtua terhadap anak intelektual. Penelitian ini menggunakan metode kualitatif deskriptif dengan teknik pengumpulan data, yaitu :1) wawancara mendalam, 2) observasi, 3) studi dokumentasi. Sumber data penelitian ini adalah sumber data primer yaitu orangtua dari anak intelektual dan sumber data sekunder berupa dokumentasi atau informasi lainnya. Hasil penelitian ini mengangkat 5 masalah yang ditemukan di lapangan yaitu pergaulan anak pada masa pandemi covid-19, perilaku anak bermain gadget pada masa pandemi covid-19, menjaga protokol kesehatan, sistem Belajar di Rumah pada masa pandemi covid-19, dan perilaku maladaptive anak disabilitas intelektual. Temuan dari penelitian ini adalah pengasuhan yang diterapkan oleh orangtua masih kurang maksimal terutama dalam berkomunikasi dan mendisiplinkan anak intelektual. Orangtua mengalami hambatan dalam berkomunikasi bersama dengan anak intelektual dikarenakan kondisi intelegensi yang menyebabkan anak susah untuk berinteraksi baik itu mengucapkan kata, mengenal kosa kata dan mengingat sesuatu. Pada aspek disiplin orangtua tidak menerapkan disiplin terhadap anak intelektual baik itu disiplin waktu dalam melakukan aktivitas maupun mendisiplinkan anak untuk menaati protokol kesehatan.
\end{abstract}

\author{
Kata Kunci: \\ Pola Asuh Orangtua, Anak Disabilitas Intelektual
}




\section{PENDAHULUAN}

Keluarga merupakan lingkungan yang paling dekat dengan anak, keluarga terutama orangtua bertugas untuk memberikan perlindungan serta kasih sayang kepada anak. Keluarga mempunyai pengaruh yang besar dalam pengasuhan kepada anak tujuan anak dapat memenuhi kebutuhan mereka secara mandiri. Orangtua wajib mendampingi anak, mengasuh anak, dan memberikan hak-hak yang seharusnya mereka miliki. Banyak keluarga khususnya para orangtua yang memandang "rendah" dan hanya bisa bergantung pada orang lain. Pola asuh orangtua merupakan gambaran tentang sikap dan perilaku orangtua dan anak dalam berinteraksi, berkomunikasi selama mengadakan kegiatan pengasuhan. Interaksi yang dimaksud adalah perilaku selama kegiatan pengasuhan dalam melakukan pendisiplinan kepada anak, memberikan perhatian, dukungan, perawatan dan mengajarkan tentang keagamaan. Interaksi yang terjalin dalam pola asuh orangtua merupakan pola perilaku yang diterapkan orangtua kepada anak secara konsisten sejak anak dilahirkan hingga remaja (Djamarah, 2014).

Peraturan Menteri Sosial Nomor 8 Tahun 2012 tentang Pedoman Pendataan dan Pengelolaan Data Pemerlu Pelayanan Masalah Kesejahteraan Sosial dan Potensi dan Sumber Kesejahteraan Sosial adalah Anak dengan Kedisabilitasan (ADK) yaitu, seseorang yang belum berusia 18 tahun mempunyai kelainan fisik atau mental yang dapat mengganggu atau merupakan rintangan dan hambatan bagi dirinya untuk melakukan fungsi-fungsi jasmani, rohani, maupun sosialnya secara layak sehingga anak disabilitas sangat membutuhkan pendampingan oleh tenaga pendidik yang berkompeten di bidang anak luar biasa. American Asociation on Mental Deficiency mendefinisikan Intelektual sebagai suatu kelainan yang fungsi intelektual umumnya di bawah rata- rata, yaitu IQ 84 ke bawah. Biasanya anak- anak intelektual akan mengalami kesulitan dalam "Adaptive Behavior" atau penyesuaian perilaku.

Pada data yang tercantum di Dinas Sosial Prov. Kalbar, 2019 jumlah disabilitas di seluruh kabupaten/kota Kalimantan Barat dari rentang umur 0-5 tahun berjumlah 76 jiwa, 618 tahun 784 jiwa dengan total keseluruhan 860 jiwa anak disabilitas.

Salah satu lembaga yang memberikan pendidikan khusus kepada anak intelektual adalah SLB Negeri Sukadana, Kabupaten Kayong Utara yang merupakan sekolah luar biasa tingkat dasar dibawah naungan Kementerian Pendidikan dan Kebudayaan. Hasil data pada tahun 2020 terdapat 23 peserta didik dan 12 peserta didik di antaranya merupakan anak intelektual dengan klasifikasi sedang. Keseluruhan guru termasuk kepala sekolah dan staf berjumlah 12, 7 diantaranya sebagai tenaga pendidik.

Pada masa pandemi semua sarana tidak berjalan atau di tutup sementara, termasuk kegiatan belajar mengajar. Gubernur Kalimantan Barat Sutarmidji memimpin konferensi pers yang dilaksanakan di Kantor Gubernur pada hari Minggu, 15 Maret 2020. Gubernur Kalimantan Barat mengungkapkan bahwa mulai Senin, 16 Maret 2020 PAUD hingga SMA Belajar di rumah sampai waktu yang belum ditentukan. Hal ini tentunya berdampak untuk orangtua, dimana orang harus memberikan pembelajaran pada anaknya dirumah. Tentu terjadi berbagai pendapat mengenai hal ini, banyak orangtua 
yang merasa keberatan ketika anak belajar di rumah, karena pada saat di rumah anak merasa bahwa bukan waktunya belajar pada saat di rumah mereka cenderung bermalas-malasan dan bermain saat di rumah, walaupun di situasi pandemi ini. Disini akan terlihat bagaimana pola asuh orangtua terhadap anak-anaknya terutama terhadap anak disabilitas intelektual saat belajar dirumah.

Hal tersebut membuat orangtua cukup kesulitan untuk menghadapi tantangan penyesuaian hidup baru pada masa pandemi covid-19 terutama dengan anak disabilitas intelektual, mengingat bahwa tidak semua orangtua memiliki latar belakang pendidikan mengenai anak dengan kedisabilitasan intelektual. Pola asuh orangtua sangat diperlukan untuk memberikan pengawasan terhadap anak disabilitas pada saat belajar di rumah. Mengingat pentingnya pola asuh orangtua dalam mengawasi, dan menjaga komunikasi terhadap anak. Sebagai orangtua hendaknya memberikan perhatian kepada anaknya, terutama perhatian terhadap informasi protokol kesehatan kepada anak disabilitas intelektual. Berdasarkan uraian tersebut, peneliti tertarik untuk meneliti sejauh mana Pola asuh orangtua terhadap anak intelektual yang ada di Sekolah Luar Biasa (SLB) Sukadana dengan rumusan masalah bagaimana karakteristik, pengawasan, komunikasi, dan disiplin orangtua anak disabilitas intelektual pada masa pandemi covid-19 di SLB Negeri Sukadana. Sehingga peneliti dapat mengetahui gambaran karakteristik, pengawasan, komunikasi, dan disiplin orangtua terhadap anak disabilitas intelektual pada masa pandemi covid-19 ini.

\section{KAJIAN LITERATUR}

\section{Pola Asuh}

Menurut Djamarah (2014) pola asuh orangtua merupakan gambaran tentang sikap dan perilaku orangtua dan anak dalam berinteraksi, berkomunikasi selama mengadakan kegiatan pengasuhan dan dalam melakukan pendisiplinan kepada anak. Interaksi yang terjalin dalam pola asuh orangtua merupakan pola perilaku yang diterapkan kepada anak secara konsisten sejak anak dilahirkan hingga remaja. Menurut Petranto (Adawiah, 2017) pola asuh orangtua merupakan pola perilaku yang diterapkan pada anak bersifat relatif konsisten dari waktu ke waktu. Pola perilaku ini dirasakan oleh anak, dari segi negatif maupun positif. Pola asuh yang ditanamkan tiap keluarga berbeda, hal ini tergantung pandangan dari tiap orangtua.

Pola asuh yang baik dapat diterapkan oleh orangtua kepada anak disabilitas, sebelum menerapkan kepada anak orangtua sebaiknya mendapatkan dukungan yang besar dari keluarga dan lingkungan sekitar. Support dari keluarga maupun lingkungan sekitar menjadi kekuatan agar orangtua dapat yakin dan percaya diri untuk memberikan pengasuhan yang baik kepada anak disabilitas. Pengasuhan yang tepat diberikan oleh orangtua kepada anak disabilitas adalah dukungan sosial yang penuh. Dukungan sosial sangat berpengaruh terhadap anak berkebutuhan khusus agar anak tidak merasa berbeda dari anak yang normal. Support, motivasi, semangat, dan penghargaan bagi mereka sangat mempengaruhi psikis anak, dengan begitu anak semakin yakin dengan potensi yang ada pada dirinya. Selain itu orangtua harus dapat mengetahui bagaimana 
kondisi kebutuhan anak. Pengasuhan yang baik kepada anak disabilitas dengan cara berkomunikasi. Jerome Burder (1975) mengatakan dengan kemampuan komunikasi antara orangtua dan anak dapat mengetahui kebutuhan-kebutuhan psikososial anak. Komunikasi yang diberikan kepada anak disabilitas tentunya berbeda tergantung dengan jenis disabilitas anak (Vani, dkk. 2014).

Menurut Mahmud (2003:9) dalam (Wiraguna, 2015) mengemukakan aspek pola asuh sebagai berikut:

\section{Pengawasan (control)}

Pengawasan dapat di identifikasikan sebagai kewaspadaan terhadap suatu objek agar tidak menyimpang dari keinginan dan tujuan sesungguhnya. Pemaknaan pengawasan mengandung pengertian antara lain upaya pengaturan, terciptanya normanorma, dan memberi batasan dengan tujuan tetap berada dalam keadaan normal atau dapat terkendalikan dengan baik.

\section{Komunikasi}

Komunikasi adalah suatu aktivitas dasar manusia yang saling berhubungan satu sama lain baik itu didalam kehidupan sehari-hari dalam rumah tangga, tempat kerjaan, masyarakat, dan dimana pun manusia berada. Komunikasi dapat dikatakan kesamaan makna mengenai suatu hal yang dikomunikasikan oleh anak dan orangtua. Dapat disimpulkan bahwa komunikasi adalah penyampaian informasi, gagasan atau suatu pesan dari suatu tempat atau orang ke yang lainnya dengan tujuan untuk tetap menjalin komunikasi dengan baik. Komunikasi menurut Effendy, 2003 dalam (Setyawan, 2018) adalah suatu proses penyampaian pesan oleh seseorang kepada orang lain untuk memberitahu, memberi pendapat, atau perilaku baik yang disampaikan secara lisan maupun tidak langsung melalui media. Menurut Marhaeni Fajar dalam bukunya yang berjudul ilmu komunikasi, teori dan praktik (2009:62) dikutip dari (Nurdianti, 2014) hambatan dalam komunikasi yaitu hambatan dari pengirim pesan, misalnya pesan yang akan disampaikan belum jelas bagi dirinya atau pengirim pesan, hal ini dipengaruhi oleh perasaan atau situasi emosional sehingga mempengaruhi motivasi, yaitu mendorong seseorang untuk bertindak sesuai keinginan, kebutuhan atau kepentingan.

\section{Disiplin}

Kedisiplinan diartikan sebagai membantu individu untuk melakukan sesuatu yang lebih baik, dengan mengajari seseorang hal yang benar mendapatkan perasaan yang nyaman serta hakiki saat melakukan sesuatu dan saat memberikan kontribusi kepada masyarakat. Kedisiplinan anak dapat dilatih dari usia dini yang dilakukan oleh orangtua yang berperan besar dalam pengasuhan anak. Melalui bentuk pendisplinan yang baik anak akan diarahkan orangtua bagaimana membiasakan diri melakukan hal-hal secara teratur dan terjadwal, dalam menerapkan disiplin tersebut orangtua dapat membuat aturan-aturan sederhana dan memberi alasan sederhana mengapa orangtua tidak bisa menerima perilaku tertentu, dan memberikan contoh yang baik terhadap anak (Guntur, 2019).

\section{Orangtua}

Orangtua yaitu terdiri dari ayah dan ibu. Orangtua memiliki peran penting dalam membimbing dan mendampingi anak-anaknya baik dalam pendidikan formal maupun non- 
formal. Orangtua atau ibu dan ayah memegang peranan penting dan sangat berpengaruh dalam pendidikan anak-anaknya. Pendidikan orangtua terhadap anaknya adalah pendidikan yang dilandasi oleh rasa cinta terhadap orangtua dan anak. Orangtua adalah awal mula dimana pendidikan anak didapat. Oleh karena itu, kasih sayang orangtua kepada anak juga harus merupakan kasih sayang sepanjang masa. Jadi dapat dipahami bahwa orangtua adalah ayah dan ibu yang bertanggung jawab atas pendidikan anak dan segala aspek kehidupannya sejak anak masih kecil hingga mereka dewasa.

Menurut Ki Hajar Dewantara dalam (Muthmainnah, 2012) menyatakan bahwa esensi pendidikan merupakan tanggung jawab keluarga, sedangkan sekolah hanya berpartisipasi. Dalam proses perkembangan anak, peran orangtua antara lain:

1. Mendampingi setiap anak yang memerlukan perhatian dari orangtuanya. Meski orangtua hanya memiliki sedikit waktu untuk mendampingi anaknya dikarenakan orangtua bekerja di luar rumah bukan berarti orangtua gagal dalam mendampingi anaknya ketika dirumah, meski hanya sedikit waktu yang dimiliki orangtua dapat memberikan perhatian dengan cara menemani anak dengan mendengar ceritanya, bercanda, bergurau atau bermain bersama.

2. Menjalin komunikasi. Komunikasi menjadi hubungan yang penting antara orangtua dan anak. komunikasi merupakan jembatan untuk mengetahui keinginan, harapan, dan respon masing-masing dari anak maupun orangtua. Melalui komunikasi orangtua dapat menyampaikan harapan dan dukungan kepada anak.
3. Memberikan kesempatan. Kesempatan pada anak dapat dimaknai sebuah kepercayaan. Kesempatan ini tidak sekedar pengawasan. Anak akan tumbuh percaya diri apabila diberikan kesempatan dalam mencoba, mengekspresikan, dan mengeksplorasi serta mengambil keputusan.

4. Mengawasi pengawasan. Pengawasan yang dimaksud bukan memata-matai atau mencurigai anak. Pengawasan yang dibangun adalah dasar komunikasi dan keterbukaan antara orangtua dan anak. orangtua dapat memantau dengan siapa dan apa yang dilakukan oleh anak untuk meminimalisir pengaruh negative pada anak.

5. Mendorong memberikan motivasi. Motivasi merupakan keadaan dalam diri individu untuk mendorong perilaku kea rah tujuan. Motivasi dapat muncul dari individu sendiri maupun dari luar individu. Setiap individu merasa senang apabila diberikan penghargaan. Motivasi diberikan kepada anak agar anak selalu berusaha dalam mencapai tujuan dan meningkatkan apa yang sudah ia capai apabila hal tersebut belum tercapai motivasi dapat membuat anak tidak menyerah.

\section{Anak Intelektual}

Menurut Sutjihati Somantri (2006: 103) intelektual adalah istilah yang digunakan untuk menyebut anak yang mempunyai kemampuan intelektual di bawah rata-rata. Dalam kepustakaan bahasa asing, digunakan istilah-istilah mental retardation, mentally retarded, mental defiency, mental defective dan lain-lain. Adapun The American Association on Mental Deficiency (dalam Sutjihati Somantri, 2012: 104) bahwa 
keterbelakangan mental menunjukkan fungsi intelektual di bawah rata-rata secara jelas dengan disertai ketidakmampuan dalam penyesuaian perilaku dan terjadi pada masa perkembangan. Ketidakmampuan ini muncul sebelum menginjak usia 18 tahun.

Berdasarkan pengertian tersebut dapat disimpulkan bahwa anak intelektual adalah suatu kondisi anak yang memiliki kelainan intelektual dan memiliki kecerdasannya jauh di bawah rata-rata dan ditandai oleh keterbatasan inteligensi dan ketidakcakapan dalam interaksi sosial. Anak tunagrahira dikenal juga dengan istilah keterbelakangan mental yang merupakan kondisi di mana perkembangan kecerdasannya mengalami hambatan sehingga tidak mencapai tahap perkembangan yang optimal, karena keterbatasan kecerdasannya mengakibatkan dirinya sukar untuk mengikuti program pendidikan di sekolah biasa, oleh karena itu anak keterbelakangan mental membutuhkan layanan pendidikan secara khusus yakni disesuaikan dengan kemampuan anak tersebut. Klasifikasi intelektual menurut Sutjihati Somantri (2012:106) mengelompokkan anak intelektual menjadi 3 bagian berdasrkan taraf intelegensinya, sebagai berikut:

\section{Intelektual Ringan}

Kelompok ini memiliki IQ antara 68-52 menurut Binet, sedangkan menurut Skala Weschler (WISC) memiliki IQ 69-55. Mereka masih dapat belajar membaca, menulis, dan berhitung sederhana. Dengan bimbingan dan pendidikan yang baik, anak terbelakang mental ringan pada saatnya akan dapat memperoleh penghasilan untuk dirinya sendiri.

2. Intelektual Sedang

Kelompok ini memiliki IQ 51-36 pada Skala Binet dan 54-40 menurut Skala
Weschler (WISC). Anak intelektual sedang sangat sulit bahkan tidak dapatbelajar secara akademik seperti belajar menulis, membaca, dan berhitung walaupun mereka masih dapat menulis secara sosial, misalnya menulis namanya sendiri, alamat rumahnya, dan lain-lain. Dapat dididik untuk mengurus diri (mandi, berpakaian, makan, minum), dan dapat mengerjakan pekerjaan rumah tangga (menyapu, membersihkan perabot rumah tangga, dan sebagainya).

3. Intelektual Berat

Kelompok anak intelektual berat dapat dibedakan lagi anak intelektual sangat berat. Intelektual berat (severe) memiliki IQ antara 35-20 menurut Skala Binet dan antara 39-25 menurut Skala Weschler (WISC). Intelektual sangat berat (profound) memiliki IQ di bawah 19 menurut Skala Binet dan IQ di bawah 24 menurut Skala Weschler (WISC). Anak intelektual berat memerlukan bantuan perawatan secara total baik itu dalam hal berpakaian, mandi, ataupun makan. Bahkan mereka memerlukan perlindungan dari bahaya sepanjang hidupnya.

\section{Virus Covid-19}

Coronavirus yang menjadi etiologi
COVID-19 termasuk dalam genus betacoronavirus. Hasil analisis filogenetik menunjukkan bahwa virus ini masuk dalam subgenus yang sama dengan coronavirus yang menyebabkan wabah Severe Acute Respiratory Illness (SARS) pada 2002-2004 silam, yaitu Sarbecovirus. (Yuliana, 2020; Susilowati, 2020). Gejala yang disebabkan oleh coronavirus ini berupa demam tinggi $>38^{\circ} \mathrm{C}$, batuk kering dan mengalami sesak nafas. Jika seseorang yang dalam 14 hari tidak muncul gejala namun ia pernah melakukan 
perjalanan ke negara atau daerah terjangkit dan pernah kontak langsung dengan penderita Covid-19, maka orang tersebut akan dilakukan pemeriksaan laboraturium untuk memastkan diagnosisnya.

Covid-19 dapat menyebar melalui tetesan kecil dari hidung atau mulut pada saat batuk atau bersin. Tetesan cairan tersebut akan menyebar jatuh pada benda-benda di sekitarnya. Jika ada orang lain menyentuh atau memegang benda yang sudah terkontaminasi dengan tetesan cairan tersebut lalu orang tersebut menyentuh mata, hidung dan mulut (pada segitiga wajah) maka orang tersebut dapat terinfeksi viruscorona. Namun bisa saja seseorang terinfeksi virus covid-19 tanpa sengaja menghirup tetesan cairan dari penderita covid-19. WHO menilai bahwa penularan dari seseorang yang tidak memiliki gejala covid-19, sangat kecil kemungkinannya terinfeksi.

\section{Pekerja Sosial}

Definisi pekerjaan sosial menurut NASW, "profesi pekerjaan sosial adalah profesi yang meningkatkan perubahan sosial, pemecahan masalah dalam hubunganhubungan manusia serta pemberdayaan dan pembebasan orang untuk meningkatkan kesejahteraan". (Adi Fahrudin, 2012: 62)

Menurut (Enung Huripah, 2014) dalam Jurnal IImiah Pekerjaan Sosial Volume 13 mengatakan bahwa Pekerjaan Sosial dengan Penyandang Disabilitas merupakan profesi pertolongan kemanusiaan memiliki peran dalam pemberian pelayanan sosial terhadap penyandang disabilitas. Upaya untuk meningkatkan kesejahteraan sosial bagi penyandang disabilitas baik kondisi kecacatannya, permasalahan sosialnya baik bersifat individual maupun pada kebijakan yang menyangkut hak penyandang disabilitas sampai pemberian pelayanan rehabilitasi sosial dan pemberdayaan bagi penyandang disabilitas, ditujukan agar dapat mencapai keberfungsian sosial.

\section{METODE PENELITIAN}

\section{Pendekatan dan Jenis Penelitian}

Pendekatan yang digunakan dalam penelitian ini adalah kualitatif dengan metode deskriptif. Pendekatan kualitatif dilakukan dengan menggunakan teknik wawancara mendalam, observasi, dan studi dokumentasi untuk mendapatkan gambaran secara langsung dan fakta di lapangan.

\section{Sumber Data dan Teknik Pengumpulan Data}

Sumber data yang digunakan dalam penelitian ini yaitu sumber data primer dan sumber data sekunder. Sumber data primer didapatkan secara langsung dari informan yang memenuhi kriteria. Selanjutnya untuk data sekunder, peneliti mendapatkan informasi melalui teknik pengumpulan data hasil observasi dan hasil studi dokumentasi, serta informasi yang tidak langsung dari informan.

\section{Pemeriksa Keabsahan Data}

Peneliti melakukan ketekunan pengamatan dengan mendengarkan kembali hasil rekaman wawancara, membaca banyak sumber, dan jurnal. Selanjutnya peneliti melakukan triangulasi yang diartikan sebagai pengecekkan data, sumber dan waktu.

\section{Teknik Analisis Data}

Analisis data dilakukan untuk menemukan makna dari setiap data yang terkumpul. Kemudian setelah data terkumpul peneliti melakukan reduksi data untuk dihubungkan dan dibandingkan antara satu dengan yang lain. Menggunakan pemikiran 
yang rasional, kritik dan logis untuk mencari perbedaan dan kesamaannya, jawaban dari informan dianalisa sehingga peneliti dapat menarik kesimpulan mengenai tanggapan yang diberikan oleh informan.

\section{HASIL PENELITIAN}

\section{Karakteristik Orangtua}

Orangtua yang memiliki anak disabilitas yang bersekolah di SLB Negeri Sukadana mayoritas berasal dari Kecamatan Sukadana. Hasil wawancara peneliti dengan informan, orangtua anak disabilitas intelektual menempuh pendidikan terakhir SLTA/SMA dengan pekerjaan ibu rumah tangga. Ayah dari anak disabilitas intelektual lah yang bekerja untuk mencari nafkah, ada yang bekerja mengumpulkan hasil dari alam seperti sayuran dan buah untuk dijual ke luar kota, lalu ada yang bekerja sebagai tukang rumah, supir truk perusahaan, pengusaha (kapal), pegawai negeri, serta penjual ikan. Selama masa pandemi covid-19, yang mengasuh anak dalam BDR (belajar dirumah), memberikan pengawasan, berkomunikasi, dan menerapkan disiplin adalah istri atau ibu dari anak disabilitas intelektual.

\section{Karakteristik Anak Intelektual}

SLB Negeri Sukadana merupakan satusatunya Sekolah Luar Biasa yang ada di Kabupaten Kayong Utara. Sebelum adanya covid-19, kegiatan anak di sekolah setiap hari senin sampai sabtu melaksanakan senam pagi di halaman untuk melatih motorik anak, setelah selesai melakukan rutinitas senam pagi para siswa masuk ke kelas masing-masing dan mulai belajar membaca dan menulis.

Anak yang bersekolah di SLB Negeri Sukadana beberapa kali mengikuti berbagai macam perlobaan SLB tingkat provinsi, perlombaan yang dimaksud adalah menggambar dan menyanyi. Meski tidak mendapatkan juara, guru mengakui bahwa perlombaan tersebut dapat dijadikan sebuah pengalaman dan dapat meningkatkan percaya diri pada anak. Pada masa pandemi covid-19, kegiatan belajar anak menjadi sistem Belajar di Rumah atau biasa disingkat BDR. Kegiatan belajar anak menurut wali kelas pada sistem BDR ini tidak cukup maksimal, dalam satu bulan hanya 2 kali wali kelas berkunjung kerumah untuk memantau perkembangan belajar anak. Hasil studi dokumentasi, peneliti mendapatkan data anak disabilitas yang bersekolah di SLB Negeri Sukadana berdasarkan kelainannya.

Tabel 1.1 Data Anak Disabilitas SLB Negeri Sukadana berdasarkan Jenis Kelainan

\begin{tabular}{|c|l|c|}
\hline No & \multicolumn{1}{|c|}{ Jenis Kelainan } & Total \\
\hline 1 & Tuna Rungu & 4 \\
\hline 2 & Intelektual Sedang & 12 \\
\hline 3 & Autis & 5 \\
\hline 4 & Down syndrome & 2 \\
\hline & Jumlah & $\mathbf{2 3}$ \\
\hline \multicolumn{2}{|c|}{ Sumber: Data Siswa SLBN Sukadana 2021 } \\
\hline
\end{tabular}

Tabel 1.1 menunjukkan data yang bersekolah di SLB Negeri Sukadana berjumlah 23 anak dengan empat macam jenis kelainan yaitu tuna rungu, intelektual sedang, autis, dan down syndrome. Terlihat bahwa jumlah anak dengan jenis intelektual sedang yang cukup banyak bersekolah di SLB Negeri Sukadana. Selanjutnya akan disajikan jumlah anak yang bersekolah di SLB Negeri Sukadana berdasarkan jenis kelamin. 
Tabel 1.2 Data anak berdasarkan jenis kelamin

\begin{tabular}{|c|l|c|c|c|}
\hline No & Jenis Kelainan & L & P & Total \\
\hline 1 & Tuna Rungu & 3 & 1 & 4 \\
\hline 2 & $\begin{array}{l}\text { Intelektual } \\
\text { Sedang }\end{array}$ & 8 & 4 & 12 \\
\hline 3 & Autis & 2 & 3 & 5 \\
\hline 4 & $\begin{array}{l}\text { Down } \\
\text { syndrome }\end{array}$ & 2 & 0 & 2 \\
\hline \multicolumn{4}{|c|}{ Sumber: Data Siswa SLBN Sukadana 2021 } \\
\hline
\end{tabular}

Tabel 1.2 dapat diketahui jumlah anak disabilitas yang bersekolah di SLB Negeri Sukadana berdasarkan jenis kelamin sebanyak 15 orang anak laki-laki, dan 8 orang anak perempuan. Jumlah anak laki-laki terbanyak adalah anak intelektual sedang yaitu 8 lakilaki.

Tabel 1.3 Data anak berdasarkan kelas

\begin{tabular}{|c|c|c|c|c|c|}
\hline No & Kelas & $\begin{array}{c}\text { Tuna } \\
\text { Rungu }\end{array}$ & $\begin{array}{c}\text { Intelektual } \\
\text { Sedang }\end{array}$ & Autis & $\begin{array}{c}\text { Down } \\
\text { syndrome }\end{array}$ \\
\hline 1 & Kelas 1 & 1 & 1 & 0 & 0 \\
\hline 2 & Kelas 2 & 1 & 2 & 0 & 0 \\
\hline 3 & Kelas 3 & 0 & 2 & 0 & 0 \\
\hline 4 & Kelas 4 & 1 & 2 & 1 & 0 \\
\hline 5 & Kelas 5 & 0 & 2 & 3 & $\mathbf{0}$ \\
\hline 6 & Kelas 6 & 1 & 3 & 1 & $\mathbf{2}$ \\
\hline Total & & $\mathbf{4}$ & $\mathbf{1 2}$ & $\mathbf{5}$ & $\mathbf{2}$ \\
\hline
\end{tabular}

Sumber: Data Siswa SLB Negeri Sukadana 2021

Berdasarkan Tabel 4.3 Data Anak Disabilitas di SLB Negeri Sukadana berdasarkan kelas yaitu Tunarungu hanya di isi kelas 1, 2, 4 dan 6 dengan total 4 orang siswa/siswi. Autis hanya di isi kelas 4, 5 dan 6 dengan total 5 orang siswa/siswi. Down syndrome hanya di isi pada kelas 6 saja dengan total 2 orang siswa. Intelektual adalah jumlah siswa/siswi terbanyak yang bersekolah di SLB Negeri Sukadana dengan kategori intelektual ringan, yang di isi pada semua kelas dengan jumlah keseluruhan adalah 12 orang siswa/siswi.

\section{Pengawasan Orangtua terhadap Anak Intelektual}

Pengawasan diidentifikasikan sebagai kewaspadaan orangtua terhadap anak agar tidak menyimpang dari keinginan dan tujuan sesungguhnya. Pemaknaan pengawasan mengandung pengertian antara lain upaya pengaturan, terciptanya norma-norma, dan memberi batasan dengan tujuan tetap berada dalam keadaan normal atau dapat terkendalikan dengan baik.

"Mun bentok pengawasan bah ye, saye ni ngawasek die selalu. Ape gik mun die ni pegi bejalan dengan kawan e, maen hp nonton tv ape saye awasi mah. Mun kirekire dah agak lama tu saye tegor, tapi dak dimarah ak soalnye die ni dak bise marahkan anak e, takot am die. Jadi cukop saye tegor"

"Kalau bentuk pengawasan, saya selalu awasi dia. Apalagi kalau dia main sama temen-temen, bermain hp atau menonton tv tetap saya awasi. Kalau sudah agak lama saya tegur, tapi saya gak marahin dia soalnya dia gak bisa dimarahin, nanti dia suka takut."

Menurut Informan bentuk pengawasan yang ia berikan kepada anaknya adalah pengawasan secara langsung. Ia cukup mengingatkan dan memberi tahu. Informan akan menyusul anaknya jika bermain terlalu lama bersama teman-teman, mengingatkan jika anaknya terlalu lama bermain gadget. Teguran yang dilakukan Informan tidak dengan teriak atau memarahi anaknya, namun 
memberikan teguran yang halus sampai anaknya menuruti.

\section{Komunikasi Orangtua dengan Anak Intelektual}

Komunikasi, yaitu bagaimana orangtua berinteraksi dengan anak, termasuk cara orangtua menerapkan aturan kepada anak, mengajarkan nilai serta norma berperilaku yang baik, serta memberikan perhatian dan kasih sayang kepada anak disabilitas.

"Sering saye ajak ngomong mah, kalau dikasik tau tu reti die. Contoh e suah die pegi sekolah pakai sepeda saye kasik tau usah kemane-mane langsong balek kerumah reti die dikasik tau tu cume care die ngomong ni susah macam tesendat gitu bah"

"Sering saya ajak ngobrol, kalau dikasi tau dia ngerti kok, contoh pernah dia pergi sekolah pakai sepeda saya kasih tau jangan kemana-mana, dia langsung pulang kerumah. Ngerti kok kalau dikasih tau, Cuma cara dia ngomong susah kayak terbata-bata gitu"

Menurut pernyataan di atas, bentuk komunikasi yang dilakukan adalah dengan memberi teguran, nasihat, dan hal-hal yang baik dan tidak baik untuk dilakukan. Orangtua selalu melakukan komunikasi bersama dengan anak intelektual meski terkadang apa yang anak sampaikan dan ucapkan masih terbatabata terkadang membuat orangtua kurang mengerti namun komunikasi antara orangtua dan anak tetap terjalin setiap harinya dibantu dengan komunikasi melalui gesture tubuh.

\section{Disiplin Orangtua terhadap Anak Intelektual}

Bentuk pendisiplinan yang diterapkan adalah bagaimana orangtua membiasakan diri melakukan hal - hal secara teratur dan terjadwal, dimana orangtua dapat menerapkan aturan-aturan sederhana dan memberikan alasan mengapa orangtua memberi aturan kepada anak.

"dak ak, paling waktu masih sekolah ye die bangon pagi. Tapi untuk buat jadwal sih ndak, ape agik kegiatan die ni cume dirumah jarang keluar sanak sinik bah jadi sehari-hari waktu nye gituk jak"

"Engga. Hanya saja saat masih sekolah dia sering bangun pagi. Tapi untuk bikin jadwal sih engga, apalagi kegiatan dia Cuma dirumah aja, jarang keluar. Jadi sehari-hari waktuny gitu-gitu aja”.

Menurut pernyataan diatas, orangtua tidak menerapkan penjadwalan terhadap pendisiplinan anak intelektual, melainkan orangtua hanya memberikan aturan secara tidak tertulis untuk aktivitas anak intelektual, seperti waktu bangun pagi, makan, waktu tidur. Orangtua tidak menerapkan disiplin terkait dengan waktu belajar anak, menjaga protokol kesehatan, dan disiplin waktu anak dalam bermain game. Orangtua merasa bahwa mendisiplinkan anak intelektual cukup sulit, sehingga orangtua hanya mengikuti mood anak saat melakukan aktivitas seperti belajar, mengerjakan tugas. Tidak jarang orangtua melanggar peraturan guru dalam waktu mengumpulkan tugas atau PR dengan alasan anak tidak mau mengerjakan tugas yang diberikan karena malas dan menunggu mood. 


\section{PEMBAHASAN}

\section{Karakteristik Informan}

Berdasarkan hasil penelitian, karakteristik informan dalam penelitian ini ada dua kategori yaitu informan utama (primer) dan informan pendukung (sekunder). Informan utama berjumlah 4 orang sedangkan informan pendukung berjumlah 4 orang. Keempat informan memberikan pengasuhan terhadap anak disabilitas intelektual. Profesi salah satu informan adalah berwirausaha yaitu memiliki warung sembako, dan salah satunya berprofesi sebagai pegawai negeri sipil, dua informan lainnya bekerja sebagai ibu rumah tangga.

Informan pendukung berjumlah 4 orang, yaitu 1 orang tetangga sekaligus keluarga informan bekerja sebagai ibu rumah tangga dan 3 orang wali kelas masing-masing anak intelektual yang bersekolah di SLB negeri Sukdana.

\section{Pengawasan Orangtua dengan Anak Intelektual}

Pengawasan adalah salah satu aspek dari pola asuh orangtua terhadap anak disabilitas intelektual menurut Mahmud 2003. Pengawasan adalah kewaspadaan terhadap suatu objek agar tidak menyimpang dari keinginan dan tujuan sesungguhnya. Berdasarkan hasil penelitian, seluruh informan memberikan pengawasan secara langsung kepada anak disabilitas intelektual.

Pengawasan yang diberikan oleh orangtua kepada anak disabilitas intelektual sudah terlaksana, seperti melakukan pengawasan terhadap pergaulan anak, melakukan control saat anak bermain gadget dan menonton tv. Pengawasan anak disabilitas intelektual lebih sering dilakukan oleh istri, dikarenakan para suami sibuk bekerja.
Orangtua sudah cukup dalam melaksanakan pengawasan terhadap anak disabilitas intelektual mulai dari mengawasi agar perilaku maladaptive tidak terjadi walau sesekali salah satu anak disabilitas intelektual dalam penelitian ini kerap merobek kertas jika melihat buku atau uang. Sebisa mungkin orangtua menjauhkan benda-benda yang dapat disobek atau dirusak oleh anak. Selain itu orangtua memberikan pengawasan terutama saat anak bermain gadget, salah satu informan mengatakan perilaku anak gemar bermain gadget semenjak memasuki masa pandemi covid-19. Salah satu orangtua dari penelitian ini mengatakan cara mengurangi kegiatan anak dalam bermain gadget, orangtua mendaftarkan anaknya ke Madrasah untuk membantu perkembangan akademik anaknya dalam ilmu agama.

Pengawasan yang dilakukan oleh orangtua anak disabilitas intelektual sudah selaras dengan teori pengawasan Mahmud, 2003. Disebutkan dalam teori pengawasan adalah kewaspadaan terhadap objek (anak) agar tidak berperilaku menyimpang dari keinginan sesungguhnya. Orangtua melakukan pengawasan terhadap anak disabilitas agar anak tidak berperilaku menyimpang dari perilaku seharusnya. Orangtua telah melakukan pengawasan setiap waktu, terkecuali dengan kondisi suami yang bekerja, suami melakukan pengawasan terhadap anak dari waktu sore hingga malam.

\section{Komunikasi Orangtua terhadap Anak Intelektual}

Salah satu aspek dari pola asuh menurut Mahmud, 2003 adalah komunikasi. Komunikasi dapat dikatakan kesamaan makna mengenai suatu hal yang dikomunikasikan 
oleh anak dan orangtua. Komunikasi menurut Effendy, 2003 dalam (Setyawan, 2018) adalah suatu proses penyampaian suatu pesan oleh seseorang (orangtua) kepada orang lain (anak) untuk memberitahu, memberi pendapat, atau perilaku baik yang disampaikan secara lisan maupun tidak.

Berdasarkan hasil penelitian, orangtua berusaha melakukan komunikasi setiap hari bersama dengan anak disabilitas intelektual, meski komunikas antara anak dan orangtua terhambat karena cara bicara anak yang terbata-bata orangtua selalu berusaha melakukan interaksi setiap harinya. Hasil wawancara, orang tua mengungkapkan cara melakukan komunikasi dengan anak disabilitas intelektual yaitu dengan mengajarkan tanggung jawab kepada anak dan memberikan teguran terhadap aktivitas anak yang berlebihan serta memberi teguran saat anak melakukan perilaku tidak baik. Contohnya perilaku salah satu anak yang selalu merobekan kertas dan melontarkan kata-kata kasar, orangtua memberikan teguran saat anak mulai merobekan kertas, mengajak anak untuk membicarakan hal lain agar anak tidak selalu fokus untuk berkata kasar. Begitu pula oramg tua yang memberikan teguran terhadap salah satu anak saat ia terlalu lama bermain gadget.

Hal ini sudah sejalan dengan teori komunikasi yang ditulis oleh Effendi, 2003. Komunikasi adalah proses penyampaian suatu pesan oleh seseorang kepada orang lain (orangtua kepada anak disabilitas intelektual) untuk memberi tahu, memberi pendapat, perilaku baik yang orangtua sampaikan secara lisan kepada anak. Mengutip teori menurut Marhaeni Fajar (2009:62) dalam Nurdianti, 2014 tentang hambatan dalam komunikasi salah satunya hambatan dari pengirim pesan, misalnya pesan yang disampaikan anak kepada orangtua belum jelas, atau sebaliknya. Hal ini dipengaruhi oleh perasaan atau situasi emosional sehingga dapat mempengaruhi anak dalam motivasi, saat komunikasi mengalami hambatan orangtua mendorong anak untuk bertindak sesuai dengan keinginan, kebutuhan atau kepentingannya. Meski terkadang komunikasi orangtua dan anak terhambat dikarenakan cara komunikasi anak yang masih terbata-bata, orangtua tetap melakukan komunikasi setiap harinya dan mencoba mengerti apa yang anak sampaikan sehingga proses komunikasi antara orangtua tetap berjalan.

\section{Disiplin Orangtua terhadap Anak Intelektual}

Disiplin merupakan salah satu aspek dari pola asuh orangtua menurut Mahmud, 2003. Kedisiplinan anak dapat dilatih dari usia dini yang dilakukan oleh orangtua yang berperan besar dalam pengasuhan anak. Melalui bentuk pendisplinan yang baik anak akan diarahkan orangtua bagaimana membiasakan diri melakukan hal-hal secara teratur dan terjadwal, dalam menerapkan disiplin tersebut orangtua dapat membuat aturan-aturan sederhana dan memberi alasan sederhana mengapa orangtua tidak bisa menerima perilaku tertentu, dan memberikan contoh yang baik terhadap anak. (Guntur, 2019)

Hasil penelitian, seluruh informanan mengungkapkan bahwa orangtua anak disabilitas intelektual pada penelitian ini tidak menerapkan disiplin secara teratur dan terjadwal melainkan hanya menunggu mood anak dalam menerapkan kedisiplinan. Orangtua cukup menyuruh anaknya untuk mengerjakan PR yang diberikan oleh guru, 
dan menegur saat anaknya melakukan aktivitas seperti bergaul bersama teman, menonton tv, bermain gadget secara berlebihan Begitupula halnya saat anak tidak menaati protokol kesehatan orangtua membiarkan anak untuk tidak memakai masker saat keluar rumah. Wali kelas anak disabilitas intelektual menuturkan bahwa salah satu orangtua kurang dalam mendisiplin waktu saat mengumpulkan tugas yang diberikan oleh guru, orangtua hanya menunggu mood anak dalam mengerjakan kewajibannya seperti mengerjakan, mengumpulkan tugas, dan belajar.

Hal ini tidak sejalan dengan teori disiplin dalam pengasuhan anak. Dimana dalam teori menyebutkan kedisiplinan dapat dilatih sejak anak usia dini. Sejak anak usia dini orangtua anak disabilitas intelektual tidak menerapkan disiplin waktu, sehingga saat ini orangtua lebih mengikuti mood anak dalam melakukan aktivitas untuk mengurangi lonjakan emosi anak disabilitas intelektual. Saat wali kelas memberikan tugas kepada anak, orangtua tidak menerapkan waktu secara konsisten dalam melaksanakan kewajiban anak untuk mengerjakan tugas yang diberikan. Orangtua hanya menunggu kesadaran anak dan mood anak untuk mengerjakan tugas yang diberikan oleh guru pada masa pembelajaran BDR (Belajar di Rumah).

\section{Penanganan Permasalahan Pola Asuh Orangtua terhadap Anak Disabilitas Intelektual pada masa Pandemi Covid-19}

Berdasarkan hasil penelitian yang telah peneliti lakukan mengenai pola asuh orangtua terhadap anak disabilitas pada masa pandemi covid-19 di SLB Negeri Sukadana. Menunjukankan bahwa pola asuh orang diberikan orangtua kepada anak disabilitas intelektual masih kurang dan perlu ditingkatkan lagi terutama dalam komunikasi dan pendisiplinan orangtua terhadap anak intelektual.

Bentuk penyelesaian masalah yang dapat diberikan kepada orangtua adalah Self Help Group. Untuk mewujudkan semua perlu adanya pola asuh yang tepat dari orangtua, terlebih pada masa covid-19 sudah seharusnya orangtua mengomunikasikan dan menerapkan disiplin untuk menjaga protokol kesehatan agar anak dan orang sekitarnya tidak terpapar virus covid-19. Program yang dibutuhkan untuk memecahkan permasalahan yang terjadi dengan teknik Self Help Group dengan nama program "Peningkatan Kemampuan Orangtua dalam Mengasuh Anak Disabilitas Intelektual pada masa Pandemi Covid-19”.

Tujuan khusus program peningkatan kemampuan orangtua dalam mengasuh anak disabilitas intelektual pada masa pendemi covid-19 adalah sebagai berikut:

1. Meningkatkan pemahaman orangtua dalam mengasuh anak disabilitas intelektual.

2. Meningkatkan kemampuan orangtua dalam mengasuh anak disabilitas intelektual.

3. Meningkatkan keterampilan orangtua dalam mengasuh anak disabilitas.

Sasarana dari usulan program ini adalah orangtua yang memiliki anak disabilits intelektual. Kegiatan yang akan dilakukan pada program ini adalah sebagai berikut:

1. Pelaksanaan Tahap I (Pra Orientasi)

Tahap I dalam pelaksanaan program ini adalah panitia mempersiapkan tempat, alat tulis untuk fasilitator dan klien.

2. Pelaksanaan Tahap II (Orientasi)

Tahap II dalam pelaksanaan program ini adalah panitia dan fasilitator membentuk 
kelompok-kelompok, dan memahami permasalahan apa yang terjadi, dan memberikan materi tentang kegiatan yang dilakukan seperti materi tentang pengasuhan yang baik terhadap anak intelektual, Self Help Group, dan koping.

3. Tahap III (Sesi Kegiatan terdiri dari 6 sesi yang dilakukan)

1) Pertemuan/sesi 1

Menentukan Topik atau identifikasi masalah

2) Pertemuan/sesi 2

Mengelompokkan masalah yang dihadapi oleh orangtua anak disabilitas intelektual

3) Pertemuan/sesi 3

Menetapkan masalah dan memecahkan masalah

4) Pertemuan/sesi 4

Memilih cara menyelesaikan masalah yang telah dicatat dalam lembar kegiatan kelompok

5) Pertemuan/sesi 5

Kegiatan ini dilakukan bersama pekerja sosial, panitia dan peserta. Panitia dapat membuat skenario permainan untuk role playing dengan tema mendisiplinkan anak disabilitas intelektual, panitia bekerja sama dengan pekerja sosial untuk melancarkan kegiatan yang diawali dengan pembentukan kelompok kecil. Satu kelompok berisi 3 orangtua yang berakting menjadi orangtua dan sebagai seorang anak. Orangtua dapat bermain peran sesuai dengan skenario yang telah dibentuk oleh panitia. Misalnya orangtua memerankan cara mendisiplinkan anak untuk melakukan aktivitas secara terjadwal atau mendisiplinkan anak untuk mematuhi protokol kesehatan.
6) Pertemuan/sesi 6

Mengingatkan kembali strategi apa yang digunakan dalam memecahkan permasalahan kelompok.

4. Tahap IV Refleksi dan penutupan

Tahap IV dalam pelaksanaan program ini adalah melakukan terminasi dan mengevaluasi seluruh kegiatan yang dilakukan. Pada poin ini ketua pelaksana atau orangtua anak intelektual dapat menyampaikan kesan, pesan, dan harapan. Serta pada poin ini menandakan berakhirnya program Peningkatan Kemampuan Orangtua dalam Mengasuh Anak Disabilitas Intelektual pada masa Pandemi Covid-19.

\section{KESIMPULAN}

Penelitian ini mengenai Pola Asuh Orangtua terhadap Anak Disabilitas Intelektual pada Masa Pandemi Covid-19 di SLB Negeri Sukadana. Karakteristik informan dalam penelitian ini terdiri dari informan utama dan informan pendukung. Orangtua ini terdiri dari 3 orang ibu dari anak disabilitas yang bekerja sebagai ibu rumah tangga dan memiliki usaha (toko sembako), dan 1 orang ayah anak disabilitas yang bekerja sebagai pegawai negeri sipil. Hasil penelitian terkait dengan pengawasan orangtua terhadap anak disabilitas intelektual yaitu orangtua melakukan pengawasan kepada anak disabilitas intelektual secara langsung dan telah melaksana pengawasan dalam hal pergaulan anak, melakukan kontrol saat anak bermain gadget dan pada saat belajar dirumah.

Permasalahan terlihat pada aspek komunikasi dan disiplin. Pada aspek komunikasi orangtua mengalami hambatan saat komunikasi dengan anak disabilitas 
dikarenakan cara bicara anak disabilitas intelektual yang kurang jelas dan terbata-bata. Anak disabilitas intelektual memiliki hambatan dalam mempelajari keterampilan berkomunikasi, sehingga mereka kesulitan berkomunikasi dengan lingkungan sekitarnya. Kurangnya intelegensi menyebabkan anak intelektual kesulitan dalam berbahasa, menangkap dan merekam informasi yang berkaitan dengan bahasa, kosa kata maupun dalam pengucapan

Selain itu permasalahan yang tampak pada penelitian ini pada aspek disiplin. Orangtua sama sekali tidak menerapkan disiplin secara tertulis keada anak saat melakukan aktivitas sehari-hari baik itu bergaul bersama teman, bermain gadget, mengerjakan tugas dan PR serta tidak menjaga protokol kesehatan. Saat anak mendapatkan tugas dari guru, orangtua hanya menunggu kesadaran anak dan mood anak untuk mengerjakan tugas yang diberikan oleh guru.

Program Self Help Group dibentuk dengan tujuan agar meningkatkan pemahan, kemampuan, dan keterampilan orangtua dalam mengasuh anak intelektual, salah satu teknik yang digunakan dalam program ini adalah role playing atau bermain peran dengan adanya permainan ini orangtua dapat meningkatkan keterampilan dalam mengasuh anak terutama dalam mendisiplinkan anak intelektual terutama pada masa pandemi ini.

Manfaat terbentuknya program Self Help Group ini dapat teralisasinya program bagi orangtua anak disabilitas dan menjalin kekompakan dan kerja sama antara pihak yang terlibat dengan orangtua anak disabilitas untuk membantu orangtua dalam memberikan pengasuhan yang tepat.

\section{DAFTAR PUSTAKA}

Adawiah, R. (2017). Pola Asuh Orangtua dan Implikasinya terhadap Pendidikan Anak: Studi pada Masyarakat Dayak di Pola Asuh Orangtua Dan Implikasinya Terhadap Pendidikan Anak (Studi pada Masyarakat Dayak di Kecamatan Halong Kabupaten Balangan) (Vol. 7, Issue 1).

Bahri, D. S. (2014). Pola Asuh Orangtua dan Komunikasi Dalam Keluarga. Jakarta: Rineka Cipta.

Dinas Sosial Prov. Kalbar. (2019). Satu Data Provinsi Kalimantan Barat. http://data.kalbarprov.go.id/organization/di nas-sosial-prov-kalbar

Guntur, N. A. (2019). Peran Orangtua Dalam Menanamkan Sikap Disiplin Anak Di Desa Kalimporo Kecamatan Bangkala Kabupaten. 1, 634.

Huripah, E. (2014). Pekerjaan Sosial dengan Disabilitas di Indonesia. Jurnal Ilmiah Pekerjaan Sosial, 13(2).

Yuliana. (2020). Corona Virus Diseases (Covid-19) Tinjauan Literatur. Wellness and Healthy Magizine, 2(February), 124137. https://doi.org/10.2307/j.ctvzxxb18.12

Muthmainnah, Peran Orangtua dalam Menumbuhkan Pribadi Anak yang Androgynius Melalui Kegiatan Bermain, Jural Pendidikan Anak,Volume, Edisi 1 (Juni 2012), 108-109.

Nurdianti, S. R. (2014). Analisis FaktorFaktor Hambatan Komunikasi Dalam Sosialisasi Program Keluarga Berencana Pada Masyarakat Kebon AgungSamarinda. Ilmu Komunikasi, 2(2), 145$159 . \quad$ http://ejournal.ilkom.fisipunmul.ac.id/site/wpcontent/uploads/2014/05/ejournal_rahma new_word (05-19-14-05-58-25).pdf

Setyawan, A. (2018). Pola Komunikasi Anak Difabel ( Intelektual ) Pada Sekolah Khusus AS-Syifa. Jurnal Ilmu Komunikasi, $V(2), 106-113$.

Susilowati, E., \& Azzasyofia, M. (2020). The parents stress level in facing children study from home in the early of covid-19 
pandemic in Indonesia. International journal of science and society, 2(3), 1-12.

Sugiyono. (2013). Metode Penelitian Kuantitatif, Kualitatif dan $R \& D$. Bandung: Alfabeda.

Sutjihati, S. (2012). Psikologi Anak Luar Biasa. Bandung: Refika Aditam

Vani, G. C., Raharjo, S. T., Hidayat, E. N., \& Humaedi, S. (2014). Pengasuhan (Good Parenting) Bagi Anak Dengan Disabilitas. Share: Social Work Journal, 4(2).

https://doi.org/10.24198/share.v4i2.13067

Wiraguna, S. (2015). Pola Asuh Keluarga Miskin Terhadap Anak Di Keluarahan Muka Kecamatan Cianjur Kabupaten Cianjur. 